\title{
Misoprostol and the Sildenafil Analog (PHAR-0099048) Modulate Cellular Efflux of cAMP and cGMP Differently
}

\section{Elin Ørvoll, Roy A. Lysaa, Aina W. Ravna, Georg Sager}

Medical Pharmacology and Toxicology, Department of Medical Biology, Faculty of Health Sciences, University of Tromsø, Tromsø, Norway.

Email: georg.sager@uit.no

Received November $13^{\text {th }}, 2012$; revised December $24^{\text {th }}, 2012$; accepted January $12^{\text {th }}, 2013$

\begin{abstract}
In the present study we have characterized ATP-dependent transport of cAMP and cGMP in physiological, but also supraphysiological concentrations. The uptake into inside-out vesicles from human erythrocytes could be dissected into two components with high and low affinity. The respective $\mathrm{K}_{\mathrm{m}}$-values were $30.8 \pm 5.2$ and $352 \pm 26 \mu \mathrm{M}$ for cAMP and $2.6 \pm 0.4$ and $260 \pm 15 \mu \mathrm{M}$ for cGMP. The two cyclic nucleotides were unable to mutually inhibit cellular efflux for concentrations up to about $100 \mu \mathrm{M}$. At higher concentrations the inhibition curve showed a steep fall. The $\mathrm{IC}_{50}$-value for cAMP reduction of high affinity $\left[{ }^{3} \mathrm{H}\right]$-cGMP transport was $695 \pm 9 \mu \mathrm{M}$. The respective value for cGMP inhibition of $\left[{ }^{3} \mathrm{H}\right]$-cAMP efflux was $284 \pm 20 \mu \mathrm{M}$. These observations are compatible with two selective high affinity transport systems. Other endogenous substances such as prostaglandins did not discriminate between cyclic nucleotide transport. The $\mathrm{IC}_{50}$ values for inhibition of $\left[{ }^{3} \mathrm{H}\right]$-cAMP and $\left[{ }^{3} \mathrm{H}\right]$-cGMP were 4.1 and $4.2 \mu \mathrm{M}$ for $\mathrm{PGE}_{1}, 2.7$ and $4.4 \mu \mathrm{M}$ for $\mathrm{PGE}_{2}$, respectively. However, the prostaglandin analog misoprostol discriminated distinctly between cAMP and cGMP transport with respective $\mathrm{IC}_{50}$-values of 4.5 and $24 \mu \mathrm{M}$. The assumption that the specific PDE5-inhibitor sildenafil could distinguish between the two cyclic nucleotides was disproved with respective $\mathrm{IC}_{50}$ values of 3.8 and $2.9 \mu \mathrm{M}$ for inhibition of $\left[{ }^{3} \mathrm{H}\right]$-cAMP and $\left[{ }^{3} \mathrm{H}\right]-\mathrm{cGMP}$, respectively. However, at least one sildenafil analog (PHAR0099048) showed a clear difference with respective $\mathrm{IC}_{50}$ values of 2.0 and $0.52 \mu \mathrm{M}$. The other tested sildenafil analogs showed no or minor ability to discriminate with $\mathrm{IC}_{50}$ values of 0.16 and $0.17 \mu \mathrm{M}$ for IS-39213, and 0.35 and $0.16 \mu \mathrm{M}$ for IS-60049, respectively. In agreement with previous reports, the present study shows that proteins responsible for cyclic nucleotide transport are multiorganic anion pumps. However, the observation that drug analogs may discriminate between these two efflux systems makes them potential drug targets.
\end{abstract}

Keywords: ABC-Transporters; cAMP; cGMP; Misoprostol; Sildenafil

\section{Introduction}

Members of the ATP-Binding-Cassette family, ABCC4, $\mathrm{ABCC} 5$ and $\mathrm{ABCC} 11$, have been identified as transport proteins for cyclic nucleotides [1-5]. The cellular efflux of these signal molecules was characterized decades ago, including cAMP (for review see [6]) and cGMP (for review see [7]). Human erythrocytes (hRBC) which possess $A B C C 4$ [8-11] and ABCC5 [1,8-10,12] are suitable for pharmacological studies of cyclic nucleotide extrusion. These cells are easily obtainable and preparation of inside-out vesicles (IOVs) makes it possible to strictly control substrate and inhibitor concentrations.

Specific inhibitors of phosphodiesterase 5 (PDE5) like sildenafil, have been identified as potent inhibitors of ABCC5-mediated cGMP cellular efflux [1]. Even if sildenafil is a potent inhibitor of cGMP efflux [13] the effect on cAMP transport has not been determined so far.
In addition we employed sildenafil derivates, identified by molecular modeling and virtual ligand screening (VLS) [14], to characterize the effect on cyclic nucleotide efflux. Three decades ago prostaglandins were shown to be potent inhibitors of cellular cAMP extrusion $[15,16]$. However, the effect on cGMP egression has previously not been studied. The aim of the present study was to characterize the transport and mutual interaction of cAMP and cGMP in physiologic and supraphysiological concentrations, and identify substances with ability to discriminate between the primary active transport systems for cyclic nucleotides.

\section{Experimental}

\subsection{Chemicals}

The following substances were employed: $\left[{ }^{3} \mathrm{H}\right]$-cGMP and $\left[{ }^{3} \mathrm{H}\right]$-cAMP (Perkin Elmer, Boston, MA), cGMP, 
cAMP, misoprostol, $\mathrm{PGE}_{1}$ and $\mathrm{PGE}_{2}$ (Sigma Aldrich, Schnelldorf, Germany), PHAR0099048, IS-39213 and IS-60049 (Ambinter, Greenpharma SAS, Orléans, France) and sildenafil (Pfizer Inc., NY). Other chemicals were of analytical grade.

\subsection{IOV Preparation}

In the present study, IOVs were prepared using a modification of the method described by Steck [17]. After collecting fresh human EDTA blood all steps were performed at $0{ }^{\circ} \mathrm{C}-4^{\circ} \mathrm{C}$. The cells were sedimented by centrifugation $(2.300 \times \mathrm{g}$ for $15 \mathrm{~min})$. Plasma and buffy coat were discarded, and the red blood cells washed three times with $5 \mathrm{mM}$ Tris- $\mathrm{HCl}, 113 \mathrm{mM} \mathrm{KCl}, \mathrm{pH} 8.1$ and centrifugation at $1000 \times \mathrm{g}$. The cells were lysed in 10 volumes of $5 \mathrm{mM}$ Tris-HCl, $0.5 \mathrm{mM}$ EGTA, $4 \mathrm{mM} \mathrm{KCl}$ $(\mathrm{pH} 8.1)$ and washed in the same buffer $(20.000 \times \mathrm{g}$ for $20 \mathrm{~min}$ ) until ghosts were milky white. Vesiculation was initiated by adding 39 volumes of $0.5 \mu \mathrm{M}$ Tris- $\mathrm{HCl}(\mathrm{pH}$ 8.2) to one volume of cell suspension and completed with homogenization, passing the suspension five times through a $27 \mathrm{G}$ cannula. The IOVs, the right-side out vesicles and ghosts were separated by ultracentrifugation $(100.000 \times \mathrm{g})$ overnight using a density gradient from $1048 \mathrm{~g} / \mathrm{ml}$ to $1146 \mathrm{~g} / \mathrm{ml}$ (Histodenz, (Sigma Aldrich, Schnelldorf, Germany) in $5 \mathrm{mM}$ Tris, $3 \mathrm{mM} \mathrm{KCl}$ and 0.3 mM EGTA. The uppermost band was collected, washed and resuspended in $1.47 \mathrm{mM} \mathrm{KH}_{2} \mathrm{PO}_{4}, 81 \mathrm{mM} \mathrm{K}_{2} \mathrm{HPO}_{4}$ and $140 \mathrm{mM} \mathrm{KCl} \mathrm{(pH} \mathrm{7.6).} \mathrm{Sidedness} \mathrm{was} \mathrm{verified} \mathrm{using}$ acetylcholinesterase accessibility according to the original method [18] with small modifications.

\subsection{Transport Assay}

In the present study $\left[{ }^{3} \mathrm{H}\right]$-cAMP and $\left[{ }^{3} \mathrm{H}\right]$-cGMP uptake into IOVs was determined in absence or in the presence of various inhibitors. IOVs were incubated for $60 \mathrm{~min}$ utes with or without $2.0 \mathrm{mM}$ ATP in a mixture containing $20 \mathrm{mM}$ Tris- $\mathrm{HCl}, 10 \mathrm{mM} \mathrm{MgCl}_{2}, 1 \mathrm{mM}$ EGTA, 2 $\mu \mathrm{M}\left[{ }^{3} \mathrm{H}\right]$-cGMP or $2 \mu \mathrm{M}\left[{ }^{3} \mathrm{H}\right]$-cAMP, $121 \mathrm{mM} \mathrm{KCl}(\mathrm{pH}$ $8.0)$ at $37^{\circ}$, and substrates or inhibitors in concentrations up to $1 \mathrm{mM}$. The transport process was terminated with addition of ice-cold $1.47 \mathrm{mM} \mathrm{KH_{2 }} \mathrm{PO}_{4}, 8.1 \mathrm{mM} \mathrm{K}_{2} \mathrm{HPO}_{4}$ and $140 \mathrm{mM} \mathrm{KCl}(\mathrm{pH} \mathrm{7.6)}$ and rapid filtration through nitrocellulose membranes $(0.22 \mu \mathrm{m}$ GSWP, Millipore, Billerica, MA) in a refrigerated laboratory $\left(4^{\circ} \mathrm{C}\right)$. The radioactivity on the filters was quantified by liquid scintillation (Ultima Gold XR, Packard, Groningen, The Netherlands) in a Packard 1900 TR Liquid Scintillation analyzer. DMSO was needed to dissolve some of the inhibitors and a similar concentration was added to the control samples.

\subsection{Data Analysis}

Hofstee-inhibition plot was used to decompose biphasic curves to obtain low and high $\mathrm{K}_{\mathrm{m}}$-values for cAMP and cGMP transport [19]. The $\mathrm{IC}_{50}$-values for inhibitors or substrates were determined according to Chou [20]. The results are presented as mean value \pm SEM of three timeindependent experiments (each in triplicate or quadriplicate) if not otherwise stated.

\section{RESULTS}

\section{1. $\left[{ }^{3} \mathrm{H}\right]-\mathrm{cAMP}$ and $\left[{ }^{3} \mathrm{H}\right]$-cGMP ATP-Dependent Transport}

ATP-dependent radiolabeled cyclic nucleotide uptake into IOVs was determined in the presence of the respective unlabeled compound in concentrations from micromolar to millimolar. The Hofstee inhibition plot [19] shows clearly that both curves are biphasic (Figure 1) and can be decomposed into high and low affinity transport with distinct differences between $\mathrm{K}_{\mathrm{m}}$-values (Table 1). The high affinity component for cAMP transport has markedly higher $\mathrm{K}_{\mathrm{m}}$-value compared to that of $\mathrm{cGMP}$.

In a previous study we found that physiologic concentrations of cAMP did not reduce high affinity cGMP transport and only with $10 \%-15 \%$ at $100 \mu \mathrm{M}$ [21]. The present work supports these observations. Figure 2 shows the effect of increasing cAMP concentrations with no or minimal displacement between 0.1 and $100 \mu \mathrm{M}$. However, from 100 to $1000 \mu \mathrm{M}$ a steep fall in $\left[{ }^{3} \mathrm{H}\right]$-cGMP transport is observed with an estimated $\mathrm{IC}_{50}$-value of 695 $\pm 9 \mu \mathrm{M}$. However, the opposite experimental setup has never been performed, that is, the ability of cGMP to reduce $\left[{ }^{3} \mathrm{H}\right]$-cAMP high affinity transport. A minimal inhibition is seen from 0.1 to $100 \mu \mathrm{M}$ cGMP, but above this concentration a clear reduction appears with an estimated $\mathrm{IC}_{50}$-value of $284 \pm 20 \mu \mathrm{M}$. This suggests that two

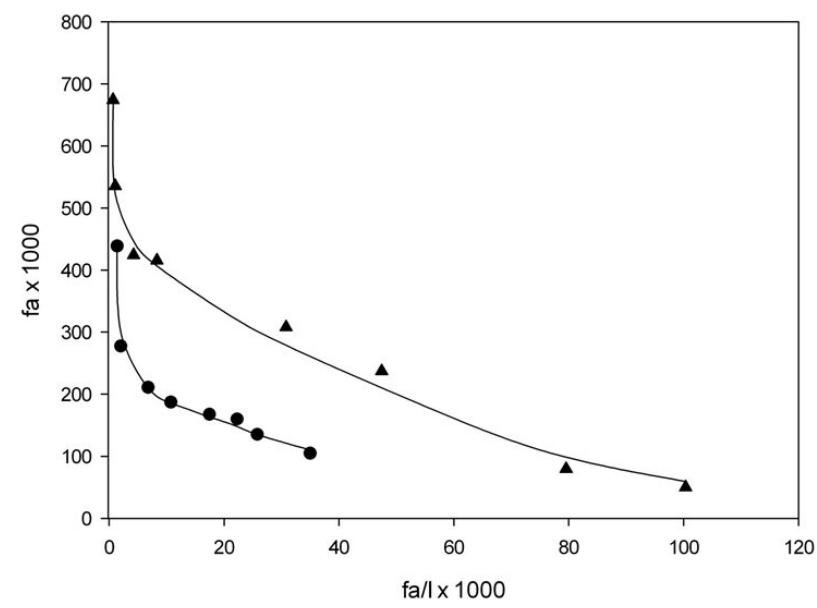

Figure 1. ATP-dependent $\left[{ }^{3} \mathrm{H}\right]$-cAMP $(n=5)$ and $\left[{ }^{3} \mathrm{H}\right]$-cGMP $(n=4)$ uptake into hRBC IOVs was determined in the presence of cAMP concentrations up to $1000 \mu M(\Delta-\Delta)$ and cGMP concentrations up to $316 \mu \mathrm{M}(\bullet-\bullet)$, respectively. 
Table 1. The data of ATP-dependent transport of $\left[{ }^{3} \mathrm{H}\right]-$ cAMP and $\left.{ }^{3} \mathrm{H}\right]$-cGMP (Figure 1) were decomposed into high and low affinity components, respectively. The $K_{\mathrm{m}^{-}}$ values are presented as mean value \pm SEM.

\begin{tabular}{ccc}
\hline & \multicolumn{2}{c}{$\mathrm{K}_{\mathrm{m}}(\mu \mathrm{M})$} \\
\cline { 2 - 3 } Substrate & High affinity & Low affinity \\
cAMP $(\mathrm{n}=5)$ & $30.8 \pm 5.2$ & $352 \pm 26$ \\
$\operatorname{cGMP}(\mathrm{n}=4)$ & $2.6 \pm 0.4$ & $260 \pm 15$ \\
\hline
\end{tabular}

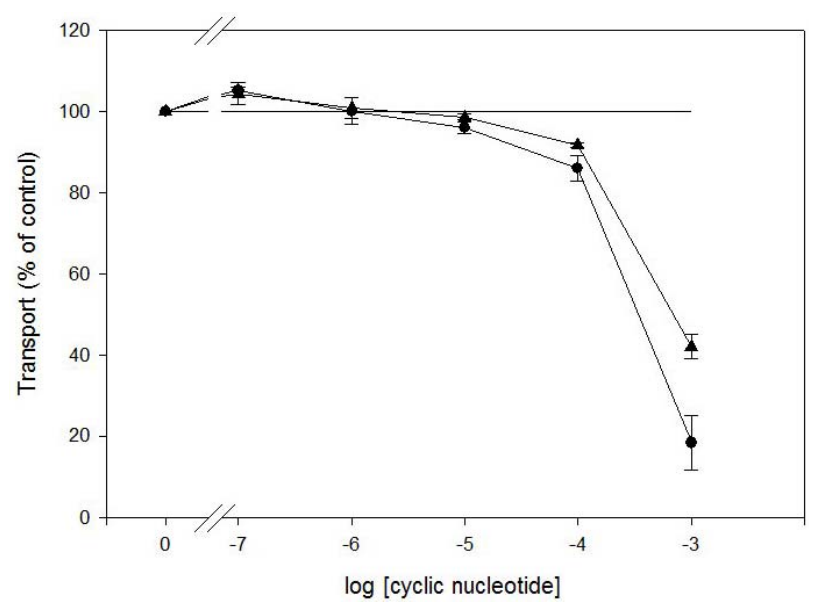

Figure 2. Inhibition of ATP-dependent $\left[{ }^{3} \mathrm{H}\right]$-cyclic nucleotide accumulation in hRBC IOVs in the presence of the other cyclic nucleotide $(0.1-1000 \mu M),\left[^{3} \mathbf{H}\right]$-cGMP/cAMP $(\Delta-\Delta)$ and $\left[{ }^{3} \mathrm{H}\right]-\mathrm{cAMP} / \mathrm{cGMP}(\bullet-\bullet)$. The results are presented as mean values \pm SEM from three separate experiments. The calculated $\mathrm{IC}_{50}$-values are given in the text.

different transporters are responsible for high affinity efflux of cyclic nucleotides from $\mathrm{hRBC}$.

\subsection{Inhibition by Prostanoids}

The prostaglandins belong to a subclass of eicosanoids, termed prostanoids and proposed as specific ABCC4substrates [22]. In the present study we tested the ability of $\mathrm{PGE}_{1}$ and $\mathrm{PGE}_{2}$ to compete with the transport of $\left[{ }^{3} \mathrm{H}\right]-$ cAMP and $\left[{ }^{3} \mathrm{H}\right]$-cGMP in physiological concentrations. They appeared to be nearly equipotent in their inhibition of cyclic nucleotide efflux (Table 2). Misoprostol is a synthetic prostanoid and a derivate of $\mathrm{PGE}_{1}$. In contrast to $\mathrm{PGE}_{1}$ misoprostol showed a distinct difference in inhibitory potency. The $\mathrm{IC}_{50}$-value was 5 -fold higher for cGMP than that of cAMP (Table 2).

\subsection{Inhibition by Sildenafil and Sildenafil Analogs}

Sildenafil is a potent PDE5 inhibitor [23] but has also the ability to inhibit cellular cGMP efflux $[1,13]$. In the present study we compared the inhibitory ability of sildenafil with sildenafil analogs. We recently demonstrated that virtual ligand screening is a useful technique to iden- tify substances even more potent than sildenafil itself [14]. Table 3 shows that sildenafil and the sildenafil derivates IS-39213 and IS-60049 were virtually equipotent in its ability to inhibit efflux of cAMP and cGMP. In contrast, PHAR0099048 distinctly inhibited cGMP efflux more strongly than that of cAMP.

\section{Discussion}

The cyclic nucleotides cAMP and cGMP are extruded from cells by an ATP-dependent process. The efflux from human erythrocytes comprises at least two components. A low affinity component was reported for cAMP transport in ghosts $\left(\mathrm{K}_{\mathrm{m}}=400-500 \mu \mathrm{M}\right)[24]$ and in the present study, for the first time for IOVs $\left(\mathrm{K}_{\mathrm{m}} \approx 350 \mu \mathrm{M}\right)$. In V79 hamster lung fibroblasts with overexpression of ABCC5 an identical affinity $\left(\mathrm{K}_{\mathrm{m}}=379 \mu \mathrm{M}\right)$ was reported for the active transport of cAMP [1]. The low affinity component of cGMP uptake into human erythrocyte IOVs has been verified by us and others, in the present and previous studies $\left(\mathrm{K}_{\mathrm{m}}=170-300 \mu \mathrm{M}\right)[8,25,26]$. A similar value $\left(\mathrm{K}_{\mathrm{m}}=180 \mu \mathrm{M}\right)$ was reported for cGMP uptake into membrane vesicles from $\mathrm{Sf} 9$ cells with overexpression of ABCC4 [27]. Recently a $\mathrm{K}_{\mathrm{m}}$-value of 630 $\mu \mathrm{M}$ was reported for cGMP transport by $\mathrm{ABCC} 4$ in wild type HEK293 cells [28].

Inhibition studies support these results. The present work showed that cAMP, below $100 \mu \mathrm{M}$, was almost unable to reduce high affinity transport of $\left[{ }^{3} \mathrm{H}\right]$-cGMP (Figure 2), compatible with a previous study [21]. Above this concentration a steep inhibition curve was seen in the present study with an $\mathrm{IC}_{50}$ of $\approx 695 \mu \mathrm{M}$. Vice versa, cGMP showed minimal inhibition of $\left[{ }^{3} \mathrm{H}\right]$-cAMP below

Table 2. The ATP-dependent transport of $\left[{ }^{3} \mathrm{H}\right]-\mathrm{cAMP}$ and $\left[{ }^{3} \mathrm{H}\right]-c G M P$ was determined in the presence of concentrations up to $100 \mu \mathrm{M}$ of $\mathrm{PGE}_{1}, \mathrm{PGE}_{2}$ and misoprostol. The $\mathrm{IC}_{50}$-values are presented as mean value $\pm \operatorname{SEM}(\mathrm{n}=3)$.

\begin{tabular}{ccc}
\hline & \multicolumn{2}{c}{$\mathrm{IC}_{50}(\mu \mathrm{M})$} \\
\cline { 2 - 3 } & {$\left[{ }^{3} \mathrm{H}\right]-\mathrm{cAMP}$} & {$\left[{ }^{3} \mathrm{H}\right]$-cGMP } \\
\hline $\mathrm{PGE}_{1}$ & $4.1 \pm 0.6$ & $4.2 \pm 0.5$ \\
$\mathrm{PGE}_{2}$ & $2.7 \pm 0.2$ & $4.4 \pm 0.7$ \\
Misoprostol & $4.5 \pm 1.2$ & $24.5 \pm 3.1$ \\
\hline
\end{tabular}

Table 3. The ATP-dependent transport of $\left[{ }^{3} \mathrm{H}\right]-\mathrm{cAMP}$ and $\left[{ }^{3} \mathrm{H}\right]$-cGMP was determined in the presence of concentrations up to $100 \mu \mathrm{M}$ of sildenafil and analogs. The $\mathrm{IC}_{50}$-values are presented as mean value \pm SEM.

\begin{tabular}{ccc}
\hline & \multicolumn{2}{c}{ IC50 $(\mu \mathrm{M})$} \\
\cline { 2 - 3 } & {$\left[{ }^{3} \mathrm{H}\right]$-cAMP } & {$\left[{ }^{3} \mathrm{H}\right]$-cGMP } \\
\hline Sildenafil & $3.8 \pm 0.9$ & $2.9 \pm 0.4^{*}$ \\
PHAR0099048 & $2.0 \pm 0.5$ & $0.52 \pm 0.03$ \\
IS-39213 & $0.16 \pm 0.07^{* *}$ & $0.17 \pm 0.01^{*}$ \\
IS-60049 & $0.35 \pm 0.03$ & $0.16 \pm 0.02$ \\
\hline
\end{tabular}


$100 \mu \mathrm{M}$ with an $\mathrm{IC}_{50}$ of $\approx 280 \mu \mathrm{M}$. A low affinity state of $\mathrm{ABCC} 4$ as well as ABCC5 may account for this since intact HEK293 cells overexpressing ABCC4 or ABCC5 showed linear transport rates for the two cyclic nucleotides up to intracellular concentrations of about $600 \mu \mathrm{M}$ [4].

The first report on cAMP transport with ABCC4 showed moderate to high affinity $\left(\mathrm{K}_{\mathrm{m}} \approx 45 \mu \mathrm{M}\right)$ [2]. This is compatible with the high affinity component of $\left[{ }^{3} \mathrm{H}\right]-$ cAMP transport in the present study $\left(\mathrm{K}_{\mathrm{m}} \approx 31 \mu \mathrm{M}\right)$. Overexpression of ABCC4 increased the cAMP efflux from intact Hep G2 cells [29]. Other authors [30-33] have confirmed that transport by ABCC4 modulates intracellular cAMP levels independently of PDE activity.

The question whether ABCC5 is involved in cGMP efflux at all, is relevant [10] since ABCC4 was reported to transport cGMP with relative high affinity $\left(\mathrm{K}_{\mathrm{m}}=9.7\right.$ $\mu \mathrm{M})$ [2]. Furthermore, ABCC4 was detected in abundance in human platelets [34] compatible with the idea that this protein is responsible for the platelet cGMP efflux [35]. ABBC5 was detected at low level in platelet plasma membrane, whereas $\mathrm{ABCC} 4$ was mainly associated with the membranes of dense granules being responsible for ADP uptake [34]. Other studies support the idea of ABCC5 as the high affinity transporter of cGMP. The prostaglandin $\mathrm{PGA}_{1}$ inhibited cGMP efflux from platelets in a concentration dependent manner [36] and was later reported to have preference for ABCC5 [4]. The report that cGMP had a very modest stimulatory effect on ABCC4 ATPase and showed an unexpected concentration-dependent pattern (non-Michaelis-Mentens kinetics) [37] questions the role of $\mathrm{ABCC} 4$ as a high affinity pump for cGMP.

ABCC5 was identified as a high affinity cGMP transporter with a $\mathrm{K}_{\mathrm{m}}$ of $2.1 \mu \mathrm{M}$ [1]. The Hofstee plot (Figure 1) in the present study gave virtually an identical $K_{m}$ value $(=2.6 \mu \mathrm{M})$, and very similar to values obtained with the same model previously $[8,21,25,26]$. Two studies have demonstrated that reduction of ABCC5 is paralleled with a marked reduction in cGMP transport. This was observed in proteoliposomes with membrane protein fractions pretreated with $\mathrm{ABCC} 5$ antibodies [12] and in pituitary GH3 cells after silencing ABCC5 [38]. In the last study the cAMP transport was unperturbed. Based on these observations the authors suggested that two pumps exist for cyclic nucleotides in pituitary cells and that ABCC5 operates as a cGMP-selective transporter [38]. The present study supports this view since neither cAMP nor cGMP were able to reduce the other's transport below $100 \mu \mathrm{M}$.

In contrast to the selectivity observed for cyclic nucleotides, $\mathrm{PGE}_{1}$ and $\mathrm{PGE}_{2}$ (Table 2), sildenafil and the sildenafil analogs IS-60049 and IS-39213 (Table 3) gave almost identical $\mathrm{IC}_{50}$-values in their inhibition of $\left[{ }^{3} \mathrm{H}\right]$ -
cAMP and $\left[{ }^{3} \mathrm{H}\right]$-cGMP. Although there has been a perception that prostaglandins have a selectivity for $\mathrm{ABCC} 4$ [10], most of these substrates have a clear effect on ABCC5 transport [39] and $\mathrm{PGA}_{1}$ had even preference for ABCC5 [4]. However, in the present study only misoprostol and the sildenafil analog PHAR0099048 showed clear selectivity between cAMP and cGMP high affinity transporters.

It is difficult to explain the present observations with a single high affinity efflux pump for cyclic nucleotides. Our hypothesis is that ABCC4 and ABCC5 represent a similar low affinity transport system with low or no selectivity and that $\mathrm{ABCC} 4$ and $\mathrm{ABCC} 5$ are responsible for high affinity transport of cAMP and cGMP, respectively. The observation that two exobiotics showed a limited but distinct discrimination between the two transport systems encourages further studies on these pumps as potential drug targets.

\section{Acknowledgements}

The financial support from the Norwegian Cancer Society and the kind gift of sildenafil from Pfizer Inc. is gratefully acknowledged. Thanks are due to Natalia Smaglyukova for excellent technical assistance.

\section{REFERENCES}

[1] G. Jedlitschky, B. Burchell and D. Keppler, "The Multidrug Resistance Protein 5 Functions as an ATP-Dependent Export Pump for Cyclic Nucleotides," The Journal of Biological Chemistry, Vol. 275, No. 39, 2000, pp. 30069-30074. doi:10.1074/jbc.M005463200

[2] Z. S. Chen, K. Lee and G. D. Kruh, "Transport of Cyclic Nucleotides and Estradiol 17-Beta-D-Glucuronide by Multidrug Resistance Protein 4. Resistance to 6-Mercaptopurine and 6-Thioguanine," The Journal of Biological Chemistry, Vol. 276, No. 36, 2001, pp. 33747-33754. doi:10.1074/jbc.M104833200

[3] M. Adachi, G. Reid and J. D. Schuetz, "Therapeutic and Biological Importance of Getting Nucleotides out of Cells: A Case for the ABC Transporters, MRP4 and 5," Advanced Drug Delivery Reviews, Vol. 54, No. 10, 2002, pp. 1333-1342. doi:10.1016/S0169-409X(02)00166-7

[4] P. R. Wielinga, D. H. van, I. G. Reid, J. H. Beijnen, J. Wijnholds and P. Borst, "Characterization of the MRP4and MRP5-Mediated Transport of Cyclic Nucleotides from Intact Cells," The Journal of Biological Chemistry, Vol. 278, No. 20, 2003, pp. 17664-17671. doi: 10.1074/jbc.M212723200

[5] Y. Guo, E. Kotova, Z. S. Chen, K. Lee, E. Hopper-Borge, M. G. Belinsky and G. D. Kruh, "MRP8 (ABCC11) Is a Cyclic Nucleotide Efflux Pump and a Resistance Factor for Fluoropyrimidines, 2'3'-Dideoxycytidine and 9'-(2'Phosphonylmethoxyethyl)-Adenine," The Journal of Biological Chemistry, Vol. 278, No. 32, 2003, pp. 29509 29514. doi:10.1074/jbc.M304059200 
[6] S. N. Orlov and N. V. Maksimova, "Efflux of Cyclic Adenosine Monophosphate from Cells: Mechanisms and Physiological Implications," Biochemistry, Vol. 64, No. 2, 1999, pp. 127-135.

[7] G. Sager, "Cyclic GMP Transporters," Neurochemistry International, Vol. 45, No. 6, 2004, pp. 865-873. doi:10.1016/j.neuint.2004.03.017

[8] A. Klokouzas, C. P. Wu, H. W. van Veen, M. A. Barrand and S. B. Hladky, "cGMP and Glutathione-Conjugate Transport in Human Erythrocytes," European Journal of Biochemistry, Vol. 270, No. 18, 2003, pp. 3696-3708. doi:10.1046/j.1432-1033.2003.03753.x

[9] C. P. Wu, H. Woodcock, S. B. Hladky and M. A. Barrand, "cGMP (Guanosine 3',5'-Cyclic Monophosphate) Transport across Human Erythrocyte Membranes," Biochemical Pharmacology, Vol. 69, No. 8, 2005, pp. 1257-1262. doi:10.1016/j.bcp.2005.02.005

[10] C. J. de Wolf, H. Yamaguchi, D. H. van, I. P. R. Wielinga, S. L. Hundscheid, N. Ono, G. L. Scheffer, H. M. de, J. D. Schuetz, J. Wijnholds and P. Borst, "cGMP Transport by Vesicles from Human and Mouse Erythrocytes," The FEBS Journal, Vol. 274, No. 2, 2007, pp. 439-450. doi:10.1111/j.1742-4658.2006.05591.x

[11] M. Rius, J. Hummel-Eisenbeiss and D. Keppler, "ATPDependent Transport of Leukotrienes B4 and C4 by the Multidrug Resistance Protein ABCC4 (MRP4)," The Journal of Pharmacology and Experimental Therapeutics, Vol. 324, No. 1, 2008, pp. 86-94. doi:10.1124/jpet.107.131342

[12] E. Boadu and G. Sager, "Reconstitution of ATP-Dependent cGMP Transport into Proteoliposomes by Membrane Proteins from Human Erythrocytes," Scandinavian Journal of Clinical and Laboratory Investigation, Vol. 64, No. 1, 2004, pp. 41-48. doi:10.1080/00365510410003895

[13] E. Sundkvist, R. Jaeger and G. Sager, "Pharmacological Characterization of the ATP-Dependent Low K(m) Guanosine 3',5'-Cyclic Monophosphate (cGMP) Transporter in Human Erythrocytes," Biochemical Pharmacology, Vol. 63, No. 5, 2002, pp. 945-949. doi:10.1016/S0006-2952(01)00940-6

[14] G. Sager, E. Orvoll, R. Lysaa, I. Kufareva, R. Abagyan and A. W. Ravna, "Novel cGMP Efflux InhibitorsIdentified by Virtual Ligand Screening (VLS) and Confirmed by Experimental Studies," Journal of Medicinal Chemistry, Vol. 55, No. 7, 2012, pp. 3049-3057. doi:10.1021/jm2014666

[15] M. J. Rindler, M. M. Bashor, N. Spitzer and M. H. Saier Jr., "Regulation of Adenosine 3':5'-Monophosphate Efflux from Animal Cells," The Journal of Biological Chemistry, Vol. 253, No. 15, 1978, pp. 5431-5436.

[16] L. L. Brunton and S. E. Mayer, "Extrusion of Cyclic AMP from Pigeon Erythrocytes," The Journal of Biological Chemistry, Vol. 254, No. 19, 1979, pp. 97149720.

[17] T. L. Steck, R. S. Weinstein, J. H. Straus and D. F. H. Wallach, "Inside-Out Cell Membrane Vesicles: Preparation and Purification," Science, Vol. 168, No. 928, 1970, pp. 255-257. doi:10.1126/science.168.3928.255
[18] G. L. Ellman, K. D. Courtney, V. Andres Jr. and R. M. Featherstone, "A New and Rapid Colorometric Determination of Acetylcholinesterase Activity," Biochemical Pharmacology, Vol. 7, 1961, pp. 88-95. doi:10.1016/0006-2952(61)90145-9

[19] G. A. McPherson, "A Mathemathical Approach to Receptor Characterization,” In: R. E. Williams, R. A. Glennon and P. B. Timmermans, Receptor Pharmacology and Function, Marcel Dekker Inc., New York, 1989, pp. 4784.

[20] T. C. Chou, "Derivation and Properties of MichaelisMenten Type and Hill Type Equations for reference Ligands," Journal of Theoretical Biology, Vol. 39, No. 2, 1976, pp. 253-276. doi:10.1016/0022-5193(76)90169-7

[21] C. Schultz, S. Vaskinn, H. Kildalsen and G. Sager, "Cyclic AMP Stimulates the Cyclic GMP Egression Pump in Human Erythrocytes: Effects of Probenecid, Verapamil, Progesterone, Theophylline, IBMX, Forskolin, and Cyclic AMP on Cyclic GMP Uptake and Association to InsideOut Vesicles," Biochemistry, Vol. 37, No. 4, 1998, pp. 1161-1166. doi:10.1021/bi9713409

[22] P. Borst, C. de Wolf and K. van de Wetering, "Multidrug Resistance-Associated Proteins 3, 4, and 5," Pflugers Archiv: European Journal of Physiology, Vol. 453, No. 5, 2007, pp. 661-673.

[23] J. D. Corbin, S. H. Francis and D. J. Webb, "Phosphodiesterase Type 5 as a Pharmacologic Target in Erectile Dysfunction," Urology, Vol. 60, No. 2, 2002, pp. 411. doi:10.1016/S0090-4295(02)01686-2

[24] G. D. Holman, "Cyclic AMP Transport in Human Erythrocyte Ghosts," Biochimica et Biophysica Acta, Vol. 508, No. 1, 1978, pp. 174-183. doi:10.1016/0005-2736(78)90199-2

[25] G. Sager, A. Orbo, R. H. Pettersen and K. E. Kjørstad, "Export of Guanosine 3',5'-Cyclic Monophosphate (cGMP) from Human Erythrocytes Characterized by Inside-Out Membrane Vesicles," Scandinavian Journal of Clinical and Laboratory Investigation, Vol. 56, No. 4, 1996, pp. 289-293. doi:10.3109/00365519609090579

[26] E. Boadu, S. Vaskinn, E. Sundkvist, R. Jaeger and G. Sager, "Inhibition by Guanosine Cyclic Monophosphate (cGMP) Analogues of Uptake of [ $\left.{ }^{3} \mathrm{H}\right] 3$ ', 5' -cGMP without Stimulation of ATPase Activity in Human Erythrocyte Inside-Out Vesicles," Biochemical Pharmacology, Vol. 62, No. 4, 2001, pp. 425-429. doi:10.1016/S0006-2952(01)00682-7

[27] R. A. van Aubel, P. H. Smeets, J. J. Van Den Heuvel and F. G. Russel, "Human Organic Anion Transporter MRP4 (ABCC4) Is an Efflux Pump for the Purine End Metabolite Urate with Multiple Allosteric Substrate Binding Sites," American Journal of Physiology. Renal Physiology, Vol. 288, No. 2, 2005, pp. F327-F333. doi:10.1152/ajprenal.00133.2004

[28] H. G. Wittgen, J. J. Van Den Heuvel, E. Krieger, G. Schaftenaar, F. G. Russel and J. B. Koenderink, "Phenylalanine 368 of Multidrug Resistance-Associated Protein 4 (MRP4/ABCC4) Plays a Crucial Role in SubstrateSpecific Transport Activity," Biochemical Pharmacology, Vol. 84, No. 3, 2012, pp. 366-373. 
doi:10.1016/j.bcp.2012.04.012

[29] L. Lai and T. M. Tan, "Role of Glutathione in the Multidrug Resistance Protein 4 (MRP4/ABCC4)-Mediated Efflux of cAMP and Resistance to Purine Analogues," Biochemical Journal, Vol. 361, No. 3, 2002, pp. 497-503. doi:10.1042/0264-6021:3610497

[30] Z. P. Lin, Y. L. Zhu, D. R. Johnson, K. P. Rice, T. Nottoli, B. C. Hains, J. McGrath, S. G. Waxman and A. C. Sartorelli, "Disruption of cAMP and PGE2 Transport by Mrp4 Deficiency Alters cAMP-Mediated Signaling and Nociceptive Response," Molecular Pharmacology, Vol. 73, No. 1, 2008, pp. 243-251. doi:10.1124/mol.107.039594

[31] Y. Sassi, L. Lipskaia, G. Vandecasteele, V. O. Nikolaev, S. N. Hatem, A. F. Cohen, F. G. Russel, N. Mougenot, C. Vrignaud, P. Lechat, A. M. Lompre and J. S. Hulot, "Multidrug Resistance-Associated Protein 4 Regulates cAMP-Dependent Signaling Pathways and Controls Human and Rat SMC Proliferation," Journal of Clinical Investigation, Vol. 118, No. 8, 2008, pp. 2747-2757. doi:10.1172/JCI35067

[32] S. Copsel, C. Garcia, F. Diez, M. Vermeulem, A. Baldi, L. G. Bianciotti, F. G. Russel, C. Shayo and C. Davio, "Multidrug Resistance Protein 4 (MRP4/ ABCC4) Regulates cAMP Cellular Levels and Controls Human Leukemia Cell Proliferation and Differentiation," The Journal of Biological Chemistry, Vol. 286, No. 9, 2011, pp. 69796988. doi:10.1074/jbc.M110.166868

[33] M. R. Rodriguez, F. Diez, M. S. Ventimiglia, V. Morales, S. Copsel, M. S. Vatta, C. A. Davio and L. G. Bianciotti, "Atrial Natriuretic Factor Stimulates Efflux of cAMP in Rat Exocrine Pancreas via Multidrug Resistance-Associated Proteins," Gastroenterology, Vol. 140, No. 4, 2011, pp. 1292-1302. doi:10.1053/j.gastro.2010.12.053

[34] G. Jedlitschky, K. Tirschmann, L. E. Lubenow, H. K. Nieuwenhuis, J. W. Akkerman, A. Greinacher and H. K.
Kroemer, "The Nucleotide Transporter MRP4 (ABCC4) Is Highly Expressed in Human Platelets and Present in Dense Granules, Indicating a Role in Mediator Storage," Blood, Vol. 104, No. 12, 2004, pp. 3603-3610. doi:10.1182/blood-2003-12-4330

[35] X. B. Wu, B. Brune, F. von Appen and V. Ullrich, "Efflux of Cyclic GMP from Activated Human Platelets," Molecular Pharmacology, Vol. 43, No. 4, 1993, pp. 564 568.

[36] W. Radziszewski, M. Chopra, A. Zembowicz, R. Gryglewski, L. J. Ignarro and G. Chaudhuri, "Nitric Oxide Donors Induce Extrusion of Cyclic GMP from Isolated Human Blood Platelets by a Mechanism Which May Be Modulated by Prostaglandins," International Journal of Cardiology, Vol. 51, No. 3, 1995, pp. 211-220. doi:10.1016/0167-5273(95)02427-X

[37] Z. E. Sauna, K. Nandigama and S. V. Ambudkar, "Multidrug Resistance Protein 4 (ABCC4)-Mediated ATP Hydrolysis: Effect of Transport Substrates and Characterization of the Post-Hydrolysis Transition State," The Journal of Biological Chemistry, Vol. 279, No. 47, 2004, pp. 48855-48864. doi:10.1074/jbc.M408849200

[38] S. A. Andric, T. S. Kostic and S. S. Stojilkovic, "Contribution of Multidrug Resistance Protein MRP5 in Control of cGMP Intracellular Signaling in Anterior Pituitary Cells," Endocrinology, Vol. 147, No. 7, 2006, pp. 34353445. doi:10.1210/en.2006-0091

[39] G. Reid, P. Wielinga, N. Zelcer, D. H. van, I, A. Kuil, M. de Haas, J. Wijnholds and P. Borst, "The Human Multidrug Resistance Protein MRP4 Functions as a Prostaglandin Efflux Transporter and Is Inhibited by Nonsteroidal Antiinflammatory Drugs," Proceedings of the National Academy of Sciences of the United States of America, Vol. 100, No. 16, 2003, pp. 9244-9249. doi:10.1073/pnas. 1033060100 